\title{
Combined geophysical investigations of the characteristics of a regional fault zone for groundwater development in a basement complex terrain of South-west Nigeria
}

\author{
Martins Olusola Olorunfemi ${ }^{1} \cdot$ Ademakinwa George Oni $^{1}$ (D) . Odunayo Emmanuel Bamidele ${ }^{2}$. \\ Taiwo Kazeem Fadare ${ }^{1} \cdot$ Odemaro Oghenekaro Aniko $^{1}$
}

Received: 3 December 2019 / Accepted: 27 February 2020 / Published online: 7 May 2020

(c) Springer Nature Switzerland AG 2020

\begin{abstract}
This paper presents the results of an integrated electrical resistivity and magnetic survey of a strike slip fault in a basement complex terrain with poor well/borehole yield. It aims to characterize the fault zone and determine its geometry, width and depth extent and attitude that will enable an assessment of its prospectivity for groundwater development. The magnetic profiles imaged a fault block characterized by a low (negative) total field magnetic anomaly with a width extent ranging from 112 to $150 \mathrm{~m}$, a depth extent in excess of $150 \mathrm{~m}$ and a near vertical disposition. The resistivity structures delineate low resistivity near vertical discontinuities within the high resistivity fresh basement host rock that correlate across the five traverses investigated. The north-western edge of the magnetic fault block and the resistivity anomalous zone correlates with the geo-referenced strike slip fault. The width of the low resistivity zone ranges from 75 to $125 \mathrm{~m}$ with depth extent in excess of $150 \mathrm{~m}$. Four subsurface geologic/geoelectric layers were delineated. These include a relatively thin topsoil underlain by a clay/sandy clay weathered basement; a partly weathered/fractured basement column and a basal fresh basement with depth to rock head of 1.6-15.0 m. A zone with thick column (up to $117 \mathrm{~m}$ ) of partly weathered/ fractured basement correlates across the traverses and significantly with the anomalous magnetic and resistivity zones. The study concludes that the thicker region of partly weathered/fractured basement column within the fault zone which is likely to have enhanced permeability and storage capacities has potential for sustainable groundwater development. It also demonstrates the effectiveness of integrated 1D and 2D electrical resistivity imaging and magnetic profiling in structure (fault) identification, characterization, subsurface sequence delineation and groundwater potential assessment in a typical basement complex environment.
\end{abstract}

Keywords Combined geophysics · Fault zone characterization · Groundwater development · Basement complex terrain

\section{Introduction}

The Obafemi Awolowo University (OAU), Ile-Ife, Southwestern Nigeria, was established in 1962 . The student and staff population had increased from 500 in 1967 to over 30,000 currently. The main source of potable water supply is through a mini dam-Opa Dam water scheme (Fig. 1) constructed in 1982 with an optimum production capacity of 1-1.2 million gallons of treated water per day, which is now grossly inadequate to meet the water requirements of the university community. This has made groundwater development an inevitable alternative water supply scheme for the community. However, several boreholes had been drilled in the past with a sizeable number abortive, some low groundwater yielding $(<1.5 \mathrm{l} / \mathrm{s})$ and very few with relatively high yield $(>1.5 \mathrm{l} / \mathrm{s})$. This could be

Ademakinwa George Oni, oniademakinwa@yahoo.com | 'Department of Geology, Obafemi Awolowo University, Ile-Ife, Osun State, Nigeria. ${ }^{2}$ Department of Geophysics, Federal University Oye-Ekiti, Oye-Ekiti, Ekiti State, Nigeria. 
Fig. 1 Topographic map of the Obafemi Awolowo University (OAU) campus, lle-Ife, showing the Opa Dam and the study area (inset is the map of Osun State, Nigeria)



attributed to inappropriate location of drill sites due to poor knowledge of the subsurface sequence and its geoelectrical characteristics when feasibility studies are not done or poorly executed.

Water supply from the Opa Dam treatment plant to the Murtala Muhammed Postgraduate Hall (MMPGH) like other parts of the university community has been inadequate and irregular, necessitating the management of MMPGH and some private organizations to attempt to develop the groundwater resource within the premises of the hall through hand-dug wells and motorized boreholes. Due to the shallowness of the hand-dug wells and the clayey nature of the weathered basement aquifer from which the wells abstract, the groundwater yields have been very low and at best moderate [1]. The success rate of the motorized boreholes has been dismally low with all the boreholes within the premises of the hall abortive. The borehole sites are characterized by generally thin overburden $(<10 \mathrm{~m})$ and un-fissured or poorly fissured grey/granite gneiss bedrock. Sustainable high groundwater yielding boreholes in basement complex environment are obtained in areas, with significantly thick weathered/ partly weathered/fractured basement, where groundwater storage and flow are significantly controlled by fractures, joints or faults [2-5].

Successful groundwater development in a basement complex environment therefore requires that the aquifer unit(s) (weathered/partly weathered and fractured basement) are delineated, their geometries clearly defined and other hydrogeological properties assessed to enable accurate location of drill sites and estimation of hydrogeologically significant borehole depths [6]. The electrical resistivity method utilizing the vertical electrical sounding (VES) technique has, over the years, found useful applications in groundwater investigation in the basement complex terrain [3, 7-12]. The applications include subsurface 
sequence delineation and aquifer identification and characterization, depth to bedrock determination, groundwater quality determination and structure (fracture, fault and fractured basement column) delineation.

The VES technique measures vertical variations in ground resistivity while assuming lateral resistivity uniformity. However, in a basement complex environment, the aquifer unit(s) (weathered and fractured basement) and hydrogeological parameters (such as thickness, depth, layer resistivity, porosity and permeability) vary both laterally and vertically [13] distorting VES curves, thereby introducing ambiguities in VES interpretation results. Although the VES technique is responsive to basement fractures as inflections on the VES curves [3,14,15], such fractured zone is assumed to be a layered hydrogeological unit for it to be delineated. Steeply inclined geologic structure such as a fault, which effectively has a 3D geometry (but is assumed 2D), could be difficult to be accurately imaged with 1D VES data gathering. When sounding profiles are aligned at an angle to the strike of a geologic structure such as a fault block, the lateral inhomogeneity is manifested as cusp on the sounding curve, which could become pronounced as the angle of inclination approaches $90^{\circ}$, as in the present survey [12]. The distortion of the sounding curves, which often is in abnormal increase in apparent resistivity (in a basement complex environment), could lead to overestimation in layer resistivity and underestimation in depth.

The vertical and lateral variability (geometric complexity) in the geoelectric characteristics of aquifer unit(s) in basement complex environment therefore favours 2D data gathering (or electrical resistivity tomography) for subsurface imaging at both shallow and deep depths [16-25]. The 2D resistivity imaging technique has found useful applications in subsurface sequence delineation, identification of aquifer unit(s), delineation of water accumulating geological structures such as faults and fractured zones, mapping of basement topography and in the overall assessment of groundwater potential in basement complex area. However, 2D subsurface images obtained from inversion of dipole-dipole data suffer model boundary deformation due to edge effect [26]. This could lead to error in estimation of depths to geoelectrical interfaces. Depths to geological targets (e.g. bottom of low resistivity fractured basement column) could be overestimated unless the anomalies are significantly strong [27].

The magnetic method, which is commonly used for the identification of magnetic minerals, has in recent time been applied in groundwater investigation. The method is useful in assessing subsurface layers overlying the bedrock, estimating thicknesses of the overburden (weathered layer) and mapping of geologic structures such as faults, fractured zones and basement topography that are favourable to groundwater accumulation in basement complex environment [21, 24].

The usefulness of the electrical resistivity method in groundwater investigation derives from the fact that aquifers (weathered/partly weathered and fractured basement) display low resistivity relative to the host while inclined geological structures such as faults are imaged as low resistivity discontinuities within a high resistivity host rock. However, in the magnetic method, the weathered layer displays relatively low magnetic susceptibility while enhanced magnetic susceptibility is observed over iron (Fe) mineralized groundwater-saturated fault zone. This leads to higher amplitude (negative) magnetic anomalies over faulted zones in a typical basement complex environment and in low magnetic latitude area $[24,28]$. An integration of the electrical resistivity and magnetic methods is therefore expected to be effective in the assessment of groundwater potential in the current basement complex area.

A regional strike slip fault, estimated to be over $5 \mathrm{~km}$ long and trending approximately $\mathrm{N}^{\circ} 0^{\circ} \mathrm{E}$, has been established at the northern part of the OAU campus $[29,30]$. The fault zone is characterized by relatively low resistivity and high (vertical component) magnetic anomaly typical of a water-saturated sheared zone with magnetic mineral (possibly deposited iron ( $\mathrm{Fe}$ ) in the water) infilling [30]. Other authors have further demonstrated the effectiveness of an integrated electrical resistivity and magnetic methods in groundwater investigation in basement complex terrain $[24,28]$. These two geophysical methods were therefore integrated in the detailed investigation and characterization of the OAU strike slip fault zone with a view to mapping the exact location of the fault; determine its geometry and depth extent and structural disposition as a means of assessing the potential of the fault zone for sustainable groundwater development.

\section{Site description}

\subsection{Geographic location and geomorphology}

The Obafemi Awolowo University (OAU) campus, Ile-Ife, South-west Nigeria, is situated within geographic coordinates of northings $828,500-836,000 \mathrm{mN}$ and eastings $666,000-671,000 \mathrm{mE}$ (Minna Zone 31) (Fig. 1). The survey area is situated at the western part of the campus with geographic coordinates of northings $831,500-832,500$ $\mathrm{mN}$ and eastings $666,700-667,600 \mathrm{mE}$. The topography is relatively flat (262-285 $\mathrm{m}$ a.s.l) but slopes gently towards the south-west (Fig. 1). The area is drained by two streams which merge and flows south-westwards (Fig. 2). 
Fig. 2 Geological map of the area around MMPGH, OAU, lleIfe (inset is the geological map of OAU campus)

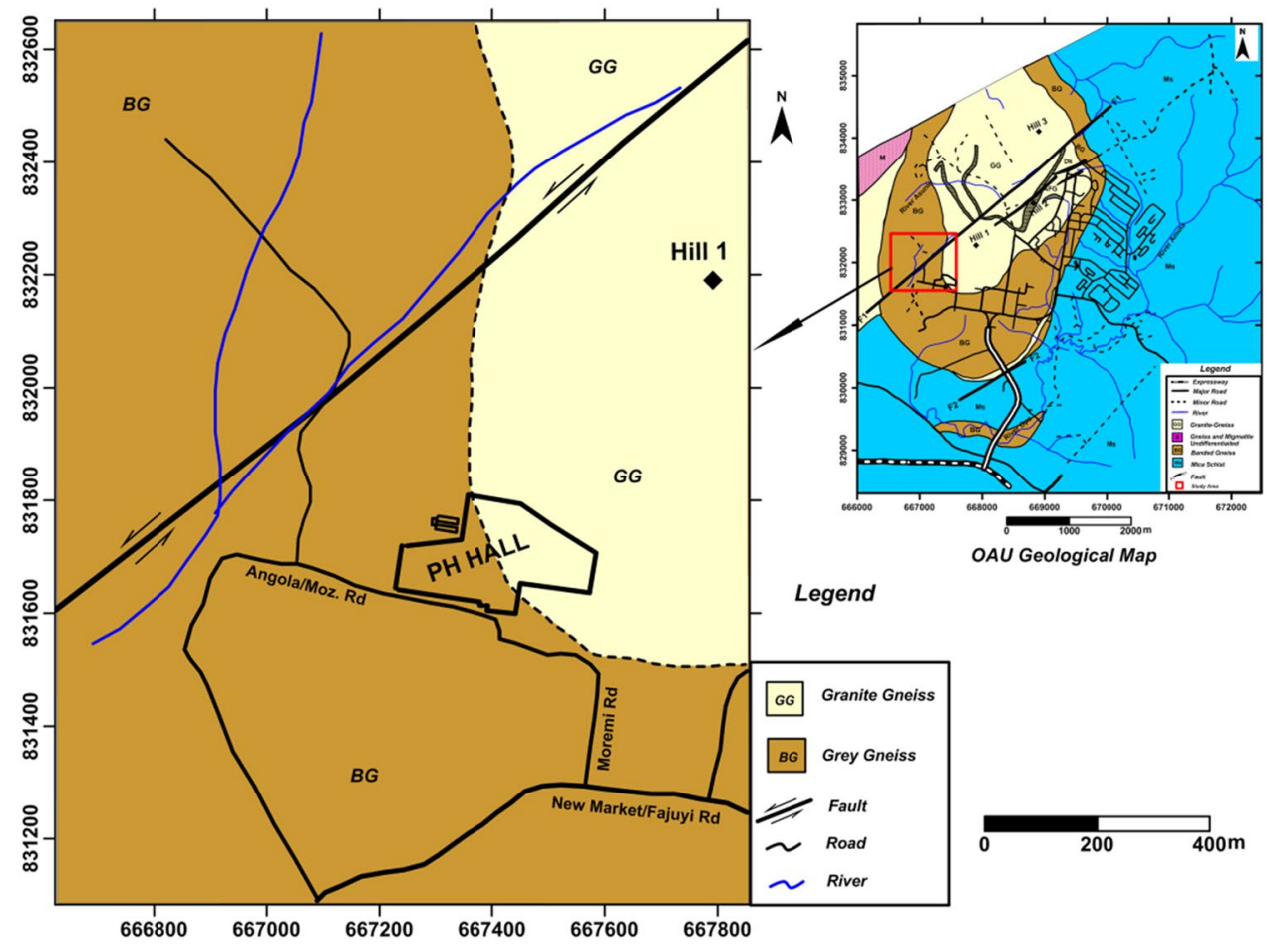

\subsection{Geology and hydrogeology}

The area around Ile-Ife falls within the western unit of the Precambrian Ilesha Schist Belt consisting of amphibolite, amphibole schists, pelitic schists, grey gneiss, granite gneiss and intrusive pegmatites and dolerite dykes. Metamorphism is mainly in the amphibolite facies but locally in the green-schist facies [31]. The survey area is primarily underlain by the grey gneiss, while the southeastern edge is underlain by granite gneiss (Fig. 2) [32]. The grey gneiss occurs as low-lying outcrops where it is exposed. It is generally greyish in colour and fine-tomedium grained in texture. It is composed of quartz, plagioclase feldspar, biotite, hornblende and zircon. The foliation planes are defined by alternation of felsic and mafic minerals. The U/Pb dating on zircon indicated an age of $2317 \pm 12 \mathrm{ma}$ [33]. The granite gneiss outcrops as inselbergs forming three prominent hills (Fig. 1). It is pinkish in colour and fine-to-medium grained. The granite gneiss is composed of quartz, potassium feldspar, biotite, hornblende, garnet and zircon. The foliation planes are also defined by mineralogical alternation of quartzo-feldspathic and ferromagnesian minerals (majorly biotite). The $\mathrm{U} / \mathrm{Pb}$ dating on zircon gave an emplacement age of 1850 ma and lower intercepts age of 510 ma, which indicate a Pan African Orogeny [33]. These rocks have been subjected to various episodes of deformation culminating in foliation, minor folds, joints and fractures.
The area is traversed by an approximately NE-SW trending strike slip fault, the characterization of which is the focus of this study. In a typical basement complex area, groundwater is contained within the weathered rocks and tectonic stress precipitated fractured/fissured, sheared or jointed basement columns. The permeability and storativity of the aquifer system are dependent on the extent and volume of fractures, fissures or joints together with the weathering thickness [2]. Groundwater yield is maximum where both weathered and fractured basement aquifers are penetrated and minimum for weathered aquifer only [3].

\section{The geophysical survey}

The geophysical investigation involved the magnetic and the electrical resistivity methods. The magnetic method utilized the profiling technique, while the electrical resistivity method adopted the $2 \mathrm{D}$ imaging technique involving the dipole-dipole array and 1D vertical electrical sounding (VES) with the Schlumberger array. The sampling interval for the magnetic profiling was $10 \mathrm{~m}$. The dipole length/station interval for the 2D imaging was $25 \mathrm{~m}$, while the current-potential dipole expansion factor, $n$, was varied from 1 to 5 . The Schlumberger array electrode spacing $(A B / 2)$ was varied from 1 to $325 \mathrm{~m}$ with a maximum spread length of $650 \mathrm{~m}$. The magnetic method was adopted as a quick reconnaissance tool for the identification of 
basement structures such as faults and fractured zones. The magnetic profiling and 2D subsurface imaging with the dipole-dipole array was carried out along five (5) traverses. Two magnetic measurements were made per station (with sensor height at $1.5 \mathrm{~m}$ ) together with readings of time. The standard procedures for magnetic data gathering were observed. Twenty-five (25) VES stations were occupied ten (10) of which were crossed soundings along the axis of the delineated strike slip fault zone. The locations of the VES stations were constrained by the dipole-dipole 2D resistivity structures (images). The GEM GSM-19T Proton Precession Magnetometer and the ABEM Terrameter SAS $300 \mathrm{C}$ digital resistivity meters were used for the total field magnetic and resistivity measurements, respectively. Figure 3 shows the geophysical traverses and the magnetic and resistivity (dipole-dipole and VES) data points.

The base point procedure was adopted for the offset/ diurnal corrections. Recordings at the base station located outside but close to the survey area were taken before, during and at the close of the fieldwork. After the raw field data were corrected for time variation and offset, the corrected magnetic data were presented as profiles. The interpretation of the magnetic profiles was both qualitative and quantitative. The qualitative interpretation involved inspection of profiles for diagnostic anomaly curves such as peak negative amplitude magnetic anomaly flanked on both sides by low-amplitude positive magnetic shoulders for thin dykes or double-negative peak amplitude magnetic anomalies with central low-amplitude positive peak flanked on both sides by low-amplitude positive peak anomaly shoulders for thick dykes, in a typical low magnetic latitude.

The ground magnetic profiles were quantitatively interpreted (modelled) using the GM-SYS plug-in of the Oasis Montaj version 6.4.2 software. The magnetic profiles were modelled using the local geomagnetic elements (inclination $(I)=-11.258^{\circ}$, declination $(D)=-1.452^{\circ}$ and horizontal magnetic field intensity $(H)=32,578 \mathrm{nT}$ ) obtained for the centre of the study area $(667,080 \mathrm{mE}, 832,036 \mathrm{mN})$ from the magnetic field calculator (IGRF-12 (2015) Model), modified as at 8 February 2019 [34]. Overburden zone and basement/fault blocks were created, and the susceptibilities of the basement/fault blocks were varied until a fit of more
Fig. 3 Data acquisition map showing the magnetic and dipole-dipole stations and the vertical electrical sounding (VES) locations

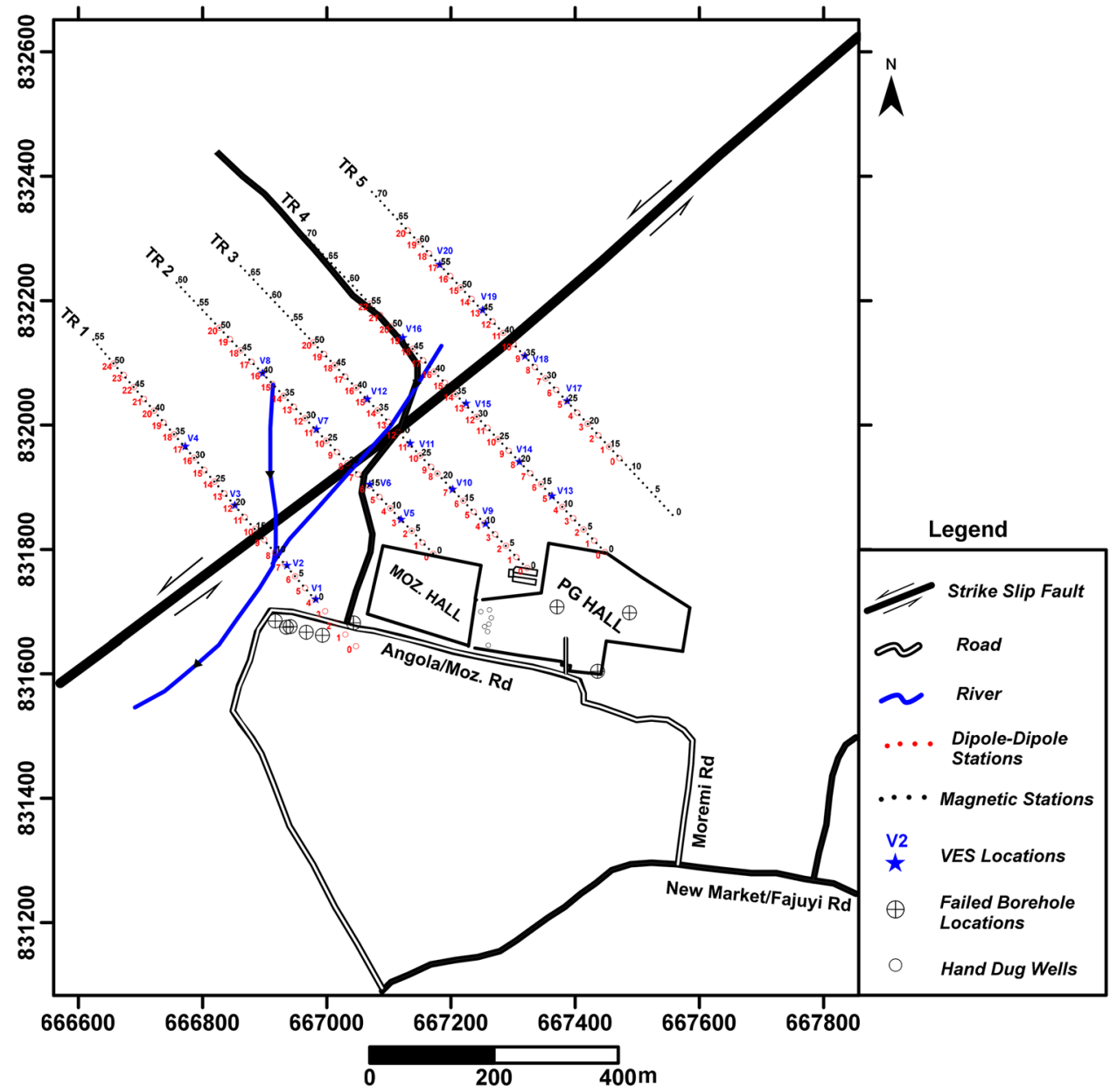

SN Applied Sciences 
than $95 \%$ was observed between the field profile and the theoretical profile. The model susceptibility values (in cgs units) varied from -0.06 to 0.085 and 0.005 to 0.014 for grey gneiss and granite gneiss basement rocks, respectively, and -0.006 to 1.0 for the fault blocks. The dipole-dipole field data were presented as pseudosections. The 2D inversion of the field data was carried out with DIPRO software with RMS errors varying from 0.15 to $0.26 \%$. The resulting $2 \mathrm{D}$ resistivity structures constitute the subsurface geoelectrical images. The VES data were presented as depth sounding curves. The quantitative interpretation of the sounding curves involved partial curve matching technique and 1D computer-assisted forward modelling with the W-GeoSoft/WinSev 5.1 software. The partial curve matching interpretation results (layer resistivities and thicknesses) constituted the starting model parameters. The VES curves were classified into type curves using layer resistivity combinations based on four principal type curves: $H\left(\rho_{1}>\rho_{2}<\rho_{3}\right), K\left(\rho_{1}<\rho_{2}>\rho_{3}\right), Q\left(\rho_{1}>\rho_{2}>\rho_{3}\right)$ and $A\left(\rho_{1}<\rho_{2}<\rho_{3}\right)$, where $\rho_{1}, \rho_{2}$ and $\rho_{3}$ are the resistivities for layers 1,2 and 3 .

\section{Results}

\subsection{Magnetic Method}

Figure 4 shows stacked profiles of the residual magnetic anomalies along the traverses. The amplitudes range from -97.5 to $+81.6 \mathrm{nT}$. The profiles are generally characterized by one major anomalous zone with two negative magnetic lows and a central high flanked by two positive generally low-amplitude shoulders, typical of a thick dyke. The anomalous zone correlates across the traverses and trend approximately NE-SW with the north-western edge of the zone coinciding with the geo-referenced strike slip fault. The 2D magnetic models (Fig. 5) show generally thin-to-moderately thick overburden $(0.2-<20 \mathrm{~m})$ with relatively thick overburden (up to $42 \mathrm{~m}$ ) generally within the modelled fault blocks (magnetic dyke). The fault blocks range in width from 112 along traverse TR 1 to $152 \mathrm{~m}$ along traverse TR 4. The depth extent is in excess of $150 \mathrm{~m}$. The north-western edge of the modelled fault blocks significantly correlates with the geo-referenced strike slip fault with the other edge shifted south-eastwards. The fault attitude (dip) is near vertical with slight south-easterly dip (Fig. 4). The characteristics of the modelled fault blocks are shown in Table 1.

\subsection{Resistivity Method}

\subsubsection{D Geoelectrical Imaging: Dipole-Dipole Profiling}

Figure $6 a-e$ displays the inverted $2 \mathrm{D}$ resistivity subsurface images (structures) along the traverses. The 2D structures identify three major subsurface layers comprising a very thin, relatively low resistivity $(<400 \Omega \mathrm{m})$, topsoil/weathered basement (in blue/green colour bands); a layer with intermediate resistivity of up to $700 \Omega \mathrm{m}$ suspected to be a partly weathered/fractured basement (a transition zone between the weathered basement and the fresh basement) (in yellowish colour band) and a basal high resistivity $(>700 \Omega \mathrm{m}$ ) layer (in brownish yellow/red/purple colour band) suspected to be the fresh basement bedrock. The models show that the depth to the very resistive fresh basement bedrock could range from as low as $<1.0 \mathrm{~m}$ (where basement rock is very shallow) to as high as greater than $100 \mathrm{~m}$ beneath the fractured basement columns.

A low resistivity vertical discontinuity within a high resistivity fresh basement host rock correlates across the $2 \mathrm{D}$ structures. The resistivity anomalous zones (vertical discontinuities) from the $2 \mathrm{D}$ resistivity structures correlate significantly with the magnetic anomalous zone with the south-eastern edge of the latter slightly shifted to the right (see Fig. 7). The north-western edge of the resistivity anomalous zone also correlates with the geo-referenced strike slip fault. The geoelectric characteristics of the fault zone are shown in Table 2.

Figure 8a-e displays the resistivity depth slice maps developed from the true resistivity values extracted from the $2 \mathrm{D}$ resistivity structures. The manifestation of the strike slip fault, as a linearly structured low resistivity zone between high resistivity host basement rock (in plan), is first noticed at depth range of $12.5-25 \mathrm{~m}$. The low resistivity structure becomes more prominent at deeper depths and clearly defined at depth levels greater than $50 \mathrm{~m}$. The structure remains prominent and well defined beyond a depth of $125 \mathrm{~m}$. This is an indication that the strike slip fault has a significant depth extent (>125 m) and must be a major (regional) structure. The upper (north-western) edge of the low resistivity structure correlates significantly with the geo-referenced position of the strike slip fault, while the lower edge is shifted south-eastwards, corroborating the inference of a fault zone.

\subsubsection{Vertical Electrical Sounding (VES)}

Within the limits of the electrode spread, the VES curves are the $\mathrm{A}, \mathrm{H}, \mathrm{AA}\left(\rho_{1}<\rho_{2}<\rho_{3}<\rho_{4}\right)$; $\mathrm{HA}\left(\rho_{1}>\rho_{2}<\rho_{3}<\rho_{4}\right)$; $\mathrm{KH}\left(\rho_{1}<\rho_{2}>\rho_{3}<\rho_{4}\right) ; \mathrm{QH}\left(\rho_{1}>\rho_{2}>\rho_{3}<\rho_{4}\right) ; \mathrm{HKH}\left(\rho_{1}>\rho_{2}<\right.$ $\left.\rho_{3}>\rho_{4}<\rho_{5}\right) ; \operatorname{KHA}\left(\rho_{1}<\rho_{2}>\rho_{3}<\rho_{4}<\rho_{5}\right)$; $\mathrm{QHA}\left(\rho_{1}>\rho_{2}>\rho_{3}\right.$ $\left.<\rho_{4}<\rho_{5}\right)$; HKHA $\left(\rho_{1}>\rho_{2}<\rho_{3}>\rho_{4}<\rho_{5}<\rho_{6}\right)$; KHAA $\left(\rho_{1}<\rho_{2}\right.$ $\left.>\rho_{3}<\rho_{4}<\rho_{5}<\rho_{6}\right)$; KHKH $\left(\rho_{1}<\rho_{2}>\rho_{3}<\rho_{4}>\rho_{5}<\rho_{6}\right)$ and HKHKH $\left(\rho_{1}>\rho_{2}<\rho_{3}>\rho_{4}<\rho_{5}>\rho_{6}<\rho_{7}\right)$ type with the H/HA type curve predominating. Typical VES curves are shown in Fig. 9. The depth sounding interpretation results are presented as correlated geoelectric sections (Fig. 10a-e). Four subsurface layers were delineated. The summaries of the 
Fig. 4 Correlated (stacked) magnetic profiles across traverses TR1-5

\section{(b)}<smiles>CC(C)(C)C</smiles>

(a)
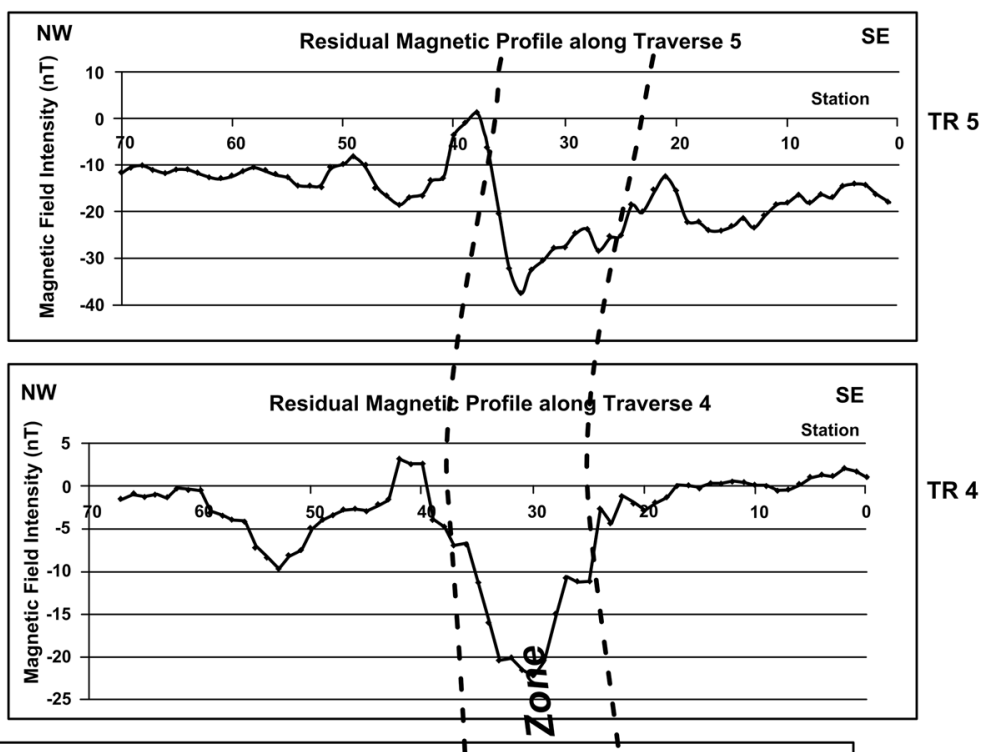

TR 4

(c)

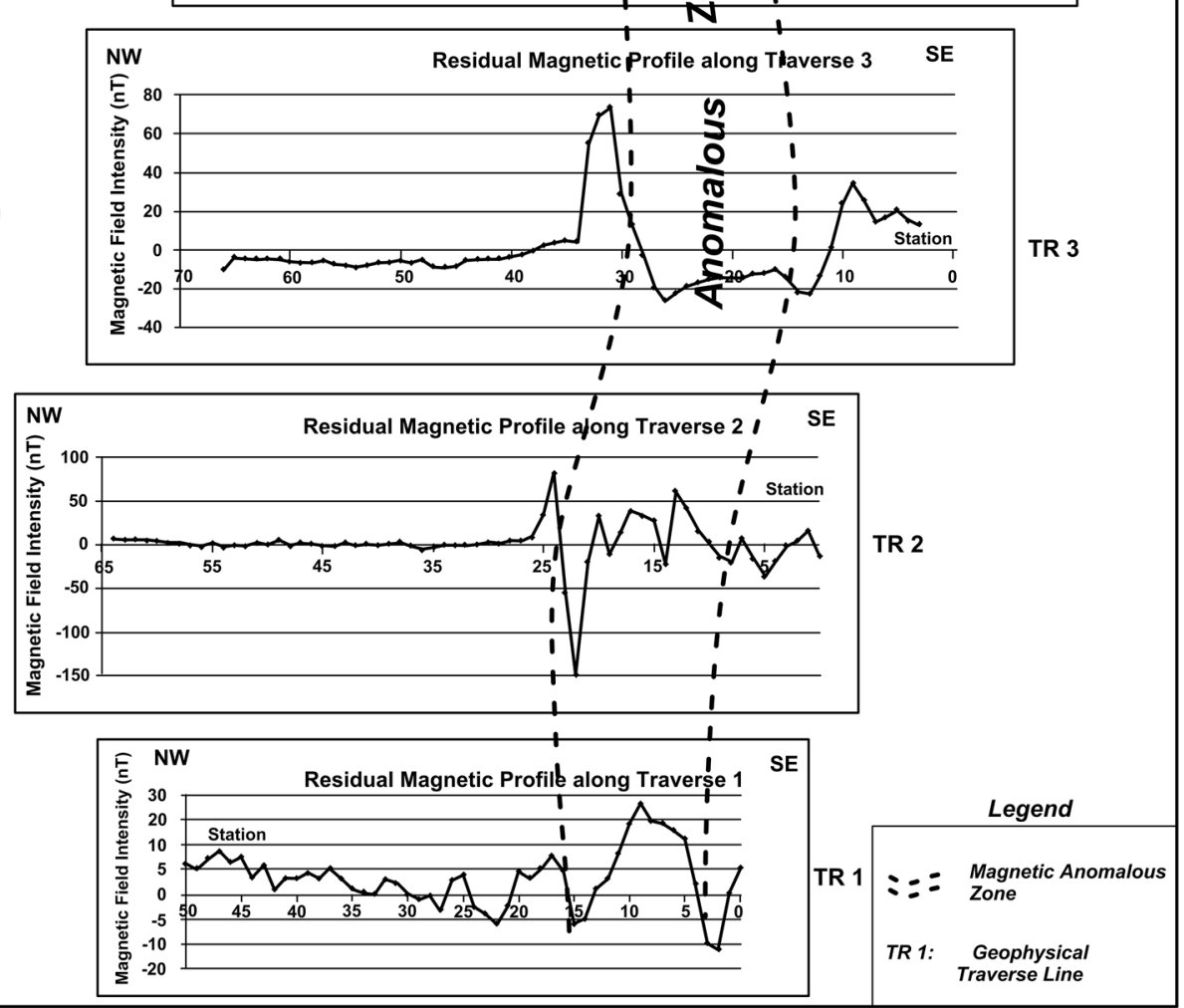

interpretation results in terms of the geoelectric/geologic layering are as follows:

1st layer (Topsoil): Clay/sandy clay/clayey sand and laterite

Layer resistivity: $68-1762 \Omega \mathrm{m}$; thickness: $0.5-2.9 \mathrm{~m}$

2nd layer (Weathered Basement): Clay/sandy clay Layer resistivity: 26-223 $\Omega \mathrm{m}$; thickness: 0.9-14.1 m 3rd layer: Partly weathered/fractured basement Layer resistivity: 54-1626 $\Omega \mathrm{m}$; thickness: 4.7-117.1 m 4th layer: Fresh basement bedrock

Layer resistivity: $755-\infty \Omega \mathrm{m}$; depth to rock head: $1.6-15.0 \mathrm{~m}$

Rock head implies top of partly weathered/fractured/ fresh basement.

The delineated thick column (up to $117 \mathrm{~m}$ ) of partly weathered/fractured basement correlates across the five traverses and significantly with the anomalous magnetic 


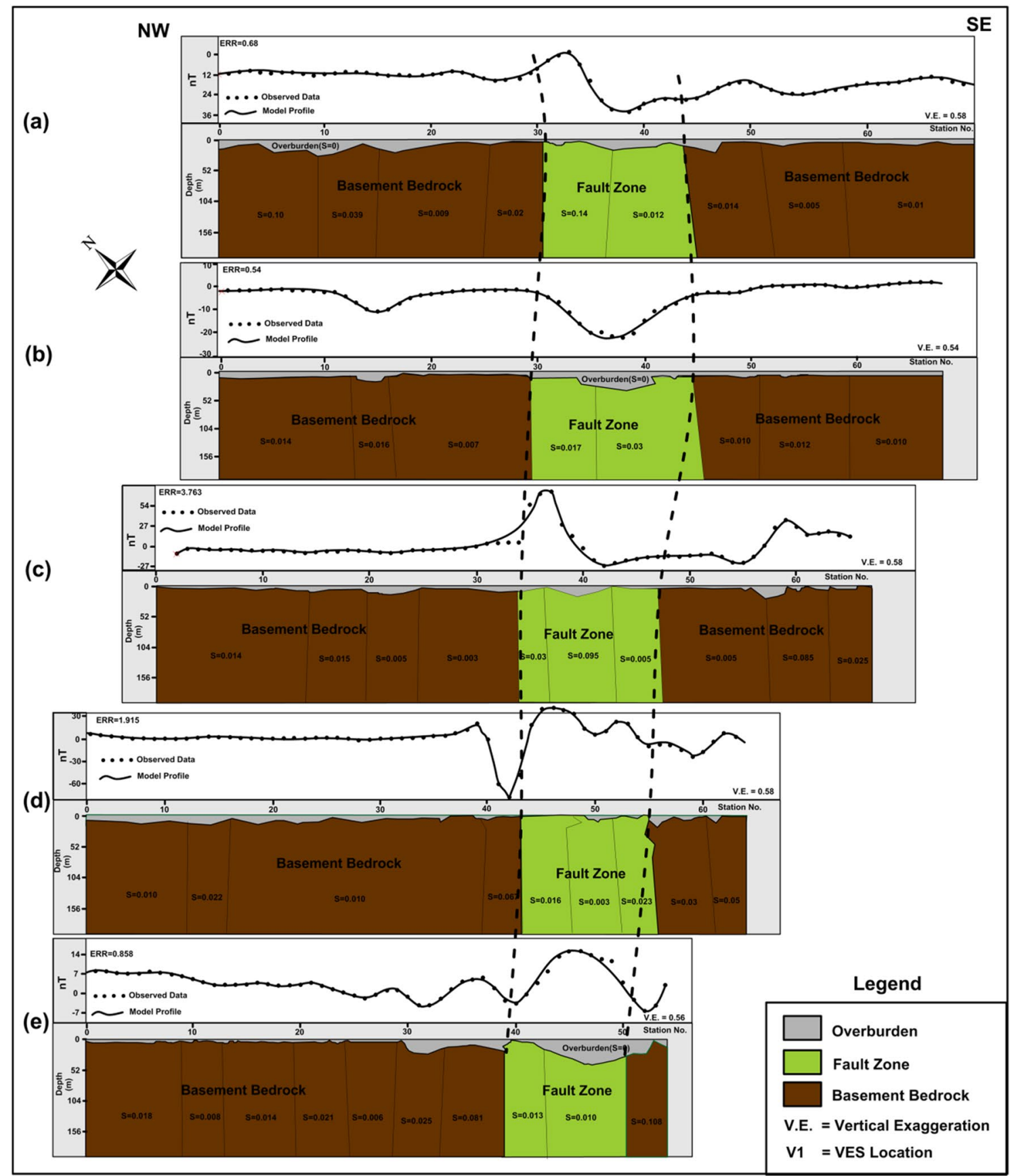

Fig. 5 Correlated magnetic profiles and models across traverses TR1-5

Table 1 Summary of characteristics of the 2D magnetic models

\begin{tabular}{lllll}
\hline Traverse & $\begin{array}{l}\text { Range of overburden } \\
\text { thickness }(\mathrm{m})\end{array}$ & $\begin{array}{l}\text { Width of fault } \\
\text { block }(\mathrm{m})\end{array}$ & $\begin{array}{l}\text { Attitude (dip) of mod- } \\
\text { elled fault zone }\end{array}$ & $\begin{array}{l}\text { Depth extent of } \\
\text { anomalous fault } \\
\text { zone }(\mathrm{m})\end{array}$ \\
\hline TR1 & $1.61-41.93$ & 112 & SE (near vertical) & $>150$ \\
TR2 & $0.28-19.96$ & 120 & SE (near vertical) & $>150$ \\
TR3 & $0.19-20.56$ & 131.5 & SE (near vertical) & $>150$ \\
TR4 & $2.19-32.06$ & 152 & SE (near vertical) & $>150$ \\
TR5 & $1.48-26.51$ & 130.7 & SE (near vertical) & $>150$ \\
\hline
\end{tabular}


NW

(a)

Traverse 5 (2-D Resistivity Structure)

TR 5

SE

(b)
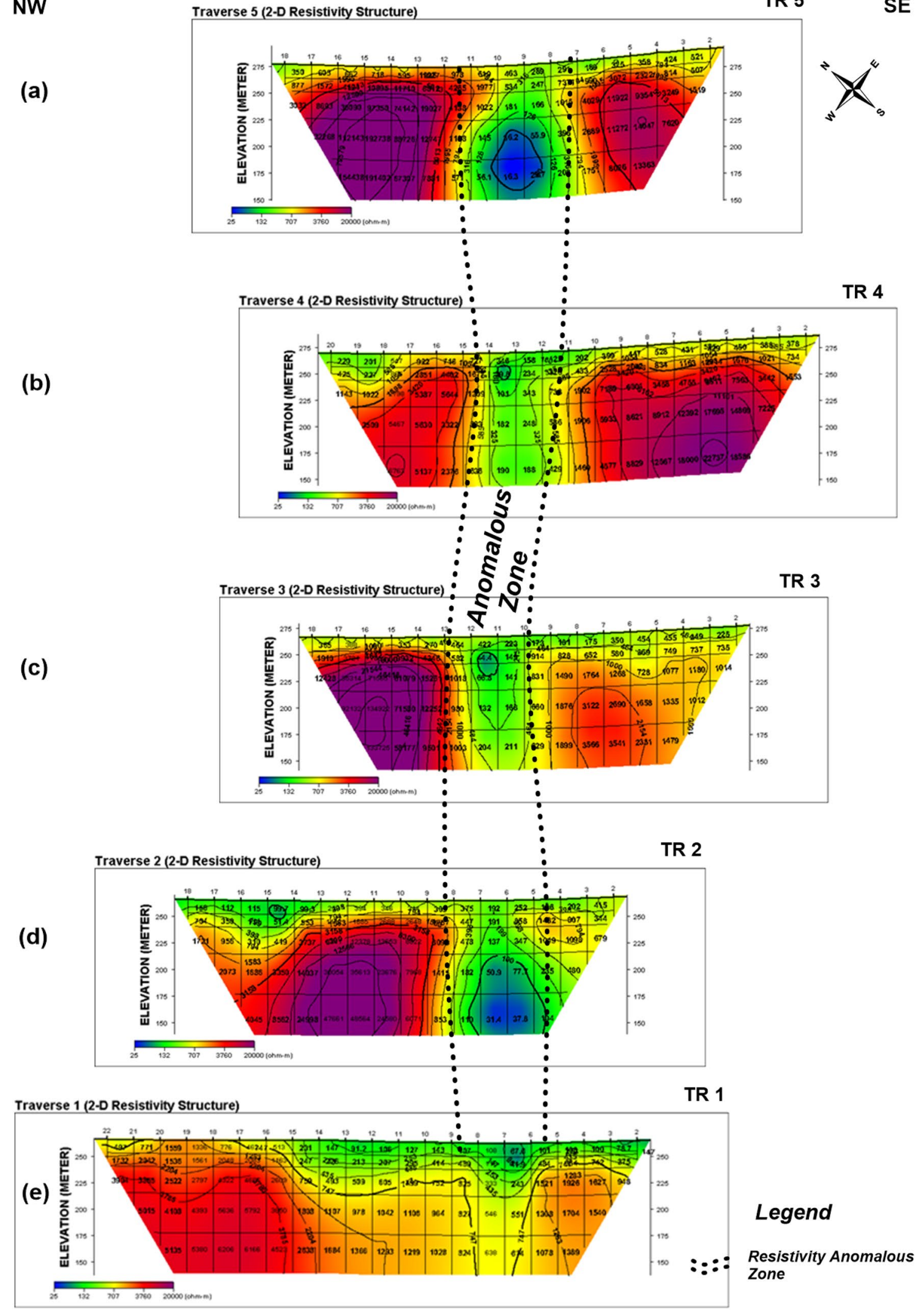

Fig. 6 Correlated 2D resistivity structures across traverses TR1-5 
Fig. 7 Structure map showing correlated magnetic and resistivity anomalous zones
Table 2 Summary of the characteristics of the fault zone

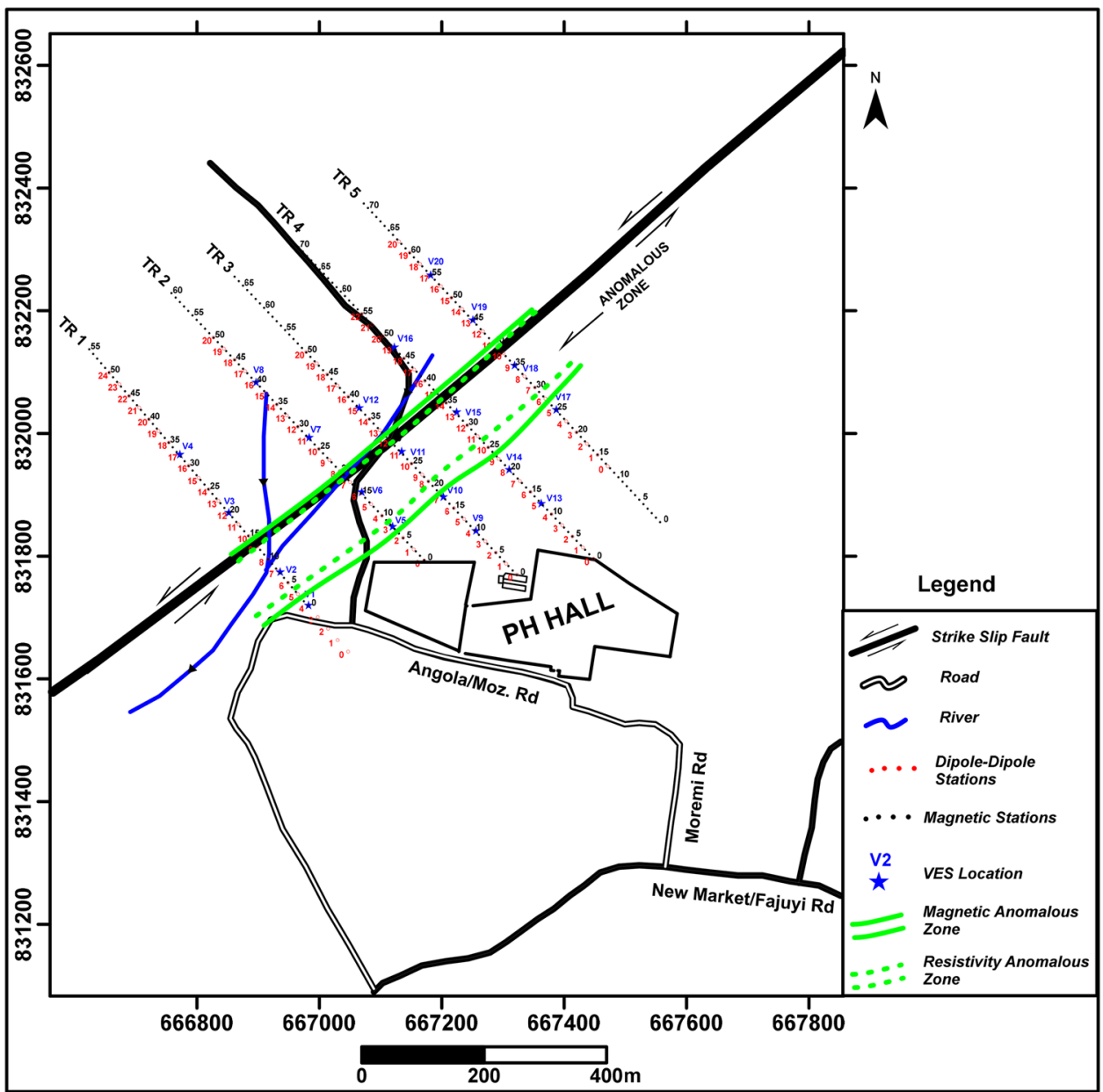

\begin{tabular}{llll}
\hline Traverse no. & Width of anomalous zone $(\mathrm{m})$ & $\begin{array}{l}\text { Top centre of anomalous } \\
\text { zone/distance from station } \\
0(\mathrm{~m})\end{array}$ & $\begin{array}{l}\text { Depth extent of anoma- } \\
\text { lously low resistivity zone } \\
(\mathrm{m})\end{array}$ \\
\hline TR 1 & Stns. $5.5-8.5(75 \mathrm{~m})$ & Stn. $7(175 \mathrm{~m})$ & $>150$ \\
TR 2 & Stns. $3-8(125 \mathrm{~m})$ & Stn. $6(150 \mathrm{~m})$ & $>150$ \\
TR 3 & Stns. $9-12.5(87.5 \mathrm{~m})$ & Stn. $11(275 \mathrm{~m})$ & $>150$ \\
TR 4 & Stns. $11-14.5(87.5 \mathrm{~m})$ & Stn. $13(325 \mathrm{~m})$ & $>100$ \\
TR 5 & Stns. $7-11(100 \mathrm{~m})$ & Stn. $9(225 \mathrm{~m})$ & $>150$ \\
\hline
\end{tabular}

and resistivity zones in Figs. 4-8 and 10, with similar approximately NE-SW trend.

\section{Discussion}

The investigated fault zone is characterized by typical thick dyke-like magnetic anomaly with two negative magnetic lows, a central high flanked by two generally low-amplitude positive shoulders. The negative magnetic anomalies are centred on the structure. Similar magnetic signatures have been observed over fractured/ faulted basement $[23,24]$. In low magnetic latitude environment, like the study area, low (negative) total field magnetic anomaly is typical of a zone with relatively high magnetic susceptibility. The investigated fault is not known to host magnetic minerals. However, fault zones are weak, weathered/fractured zones with enhanced effective porosity that are often groundwater saturated. Fault zones within a basement complex terrain are characterized by fractures. When fractured basement rock encounters water, chemical weathering occurs leading 

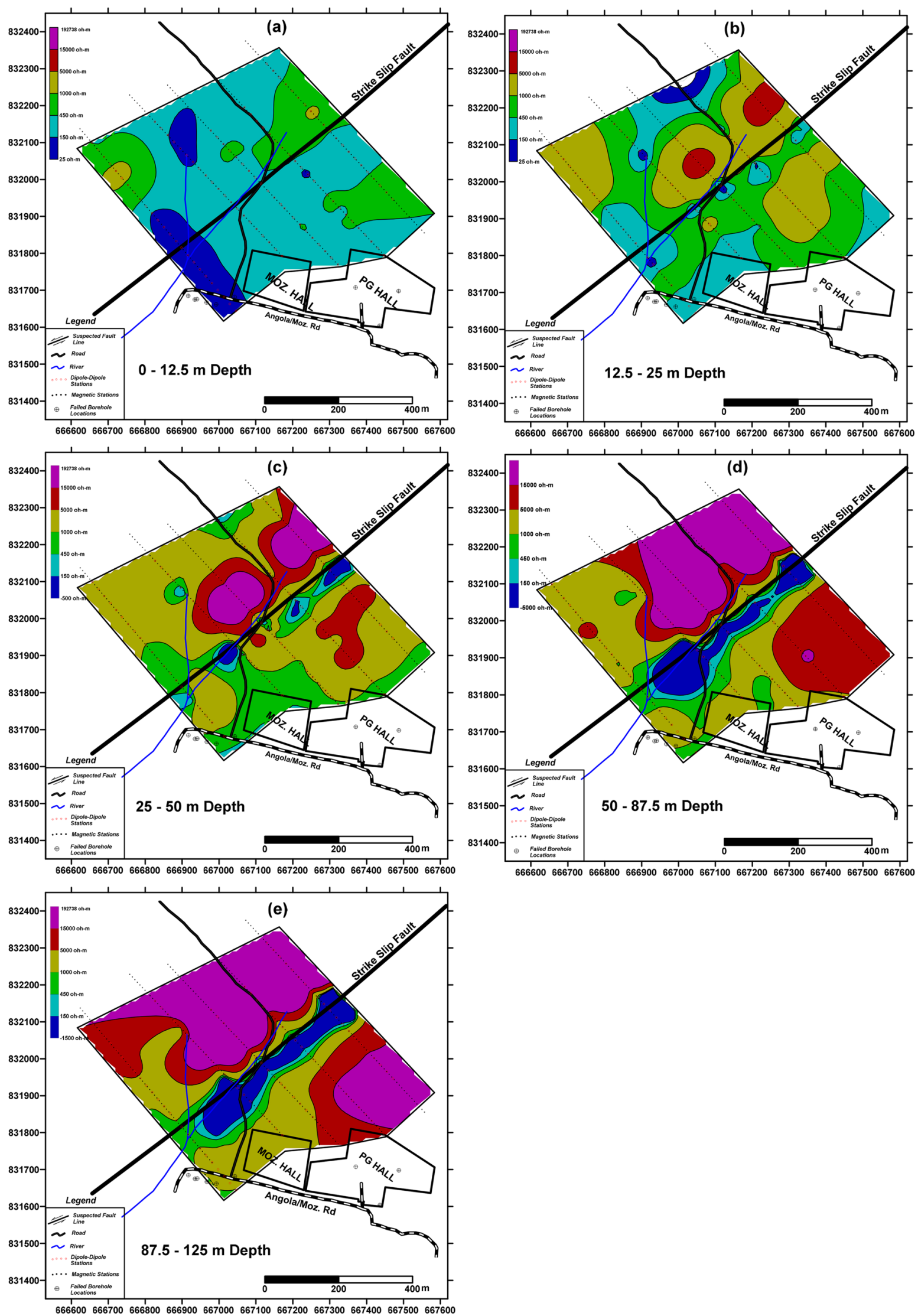

Fig. 8 Resistivity depth slice maps at a 0-12.5 m, b 12.5-25 m, c 25-50 m, d 50-87.5 m and e 87.5-125 m depth levels 


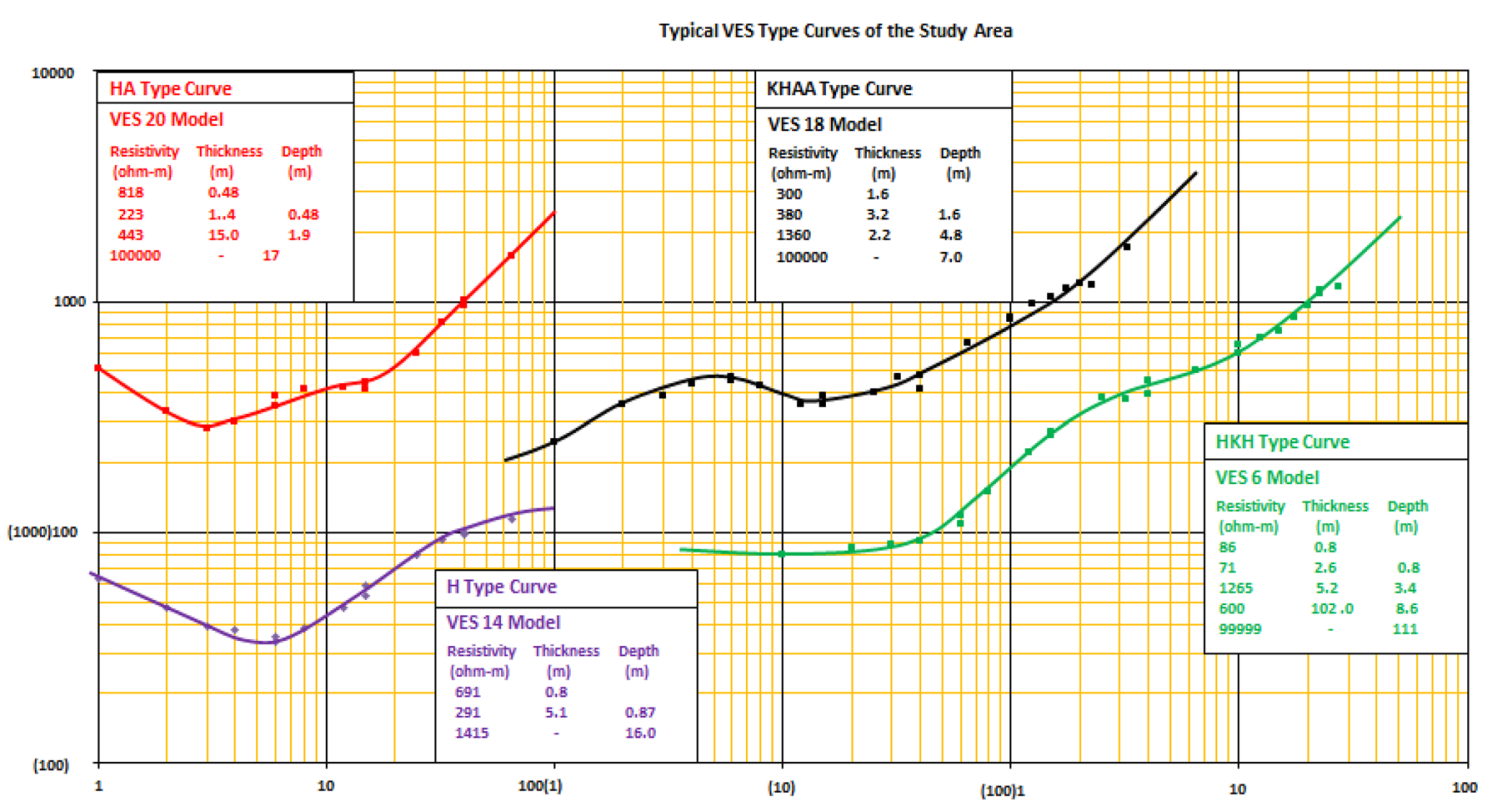

Fig. 9 Typical VES curves in the study area

to formation of oxidation-iron stains on the fracture planes [4]. Deposited iron (Fe) from weathered rocks within the fault zone, over geologic time, could have led to enhanced magnetic susceptibility of the fault zone and the resultant low (negative) magnetic anomaly.

The VES type curves that range from simple three layers $\mathrm{A}$ and $\mathrm{H}$ types to complex four-seven layers $\mathrm{HKH}$, $\mathrm{KHKH}$ and HKHKH types show the complexity of the subsurface sequence in the study area. Inflections and resistivity lows on the $\mathrm{HKH}, \mathrm{KHA}, \mathrm{HKH}, \mathrm{HKHA}, \mathrm{KHKH}$ and HKHKH type curves are indicative of unconfined and confined basement fractured columns [3]. Four subsurface geologic layers (which include the topsoil, weathered layer, partly weathered/fractured basement and fresh basement) were delineated from the geoelectric sections generated from interpreted results of the VES curves. The topsoil is thin (generally $<1 \mathrm{~m}$ ) and overlaps with the weathered layer in resistivity and is hence imaged with the weathered layer on the $2 D$ resistivity structures. The layer resistivity values of the delineated subsurface layers derived from the geoelectric sections and $2 \mathrm{D}$ resistivity structures are shown in Table 3 . These values are compared with ranges of resistivity values obtained by other authors in similar geologic environment $[4,23,28]$. The weathering profile model (topsoil, weathered layer, partly weathered/fractured basement and fresh basement) obtained from this study conforms with the simplified weathering profile of a typical basement complex terrain [35] which is also corroborated by the work of authors such as Mcfarlane [36] (as colluvium, saprolite, saprock and fresh rock); Wright [37] (as stoneline, saprolite, saprock and fresh rock); and Dewandel et al. [4] (as laterite, saprolite, fissured layer and fresh basement).

The fault zone, identified as partly weathered/fractured basement, displays resistivity values that overlap with that of the weathered layer and transit into the lower range of the fresh basement resistivity. On both the correlated geoelectric sections and 2D resistivity structures, the fault zone manifests as low resistivity discontinuity within a highly resistive fresh basement host rock. The estimated depth extent of the fault zone from the geoelectric section (maximum of $117 \mathrm{~m}$ ) is less than the over $150 \mathrm{~m}$ estimated from the $2 \mathrm{D}$ resistivity structures and depth slice resistivity maps. The lower depth extent estimated from the 1DVES curves could be due to distortion of the VES curves arising from sounding profiles whose alignments are at high angle to the strike of the geologic structure [12].

As observed earlier, a fault zone in a basement terrain is characterized by fractures. The interaction of fractured basement with groundwater precipitates the weathering of micaceous minerals (most especially biotite) and other ferromagnesian minerals into clays which induce expansion and further fissuring of the fractured basement $[4$, 38-40]. This process increases the effective porosity, permeability, storage capacity and the width extent of the fractured aquifer. The groundwater saturation, increased effective porosity and the ion exchange capacity of the 


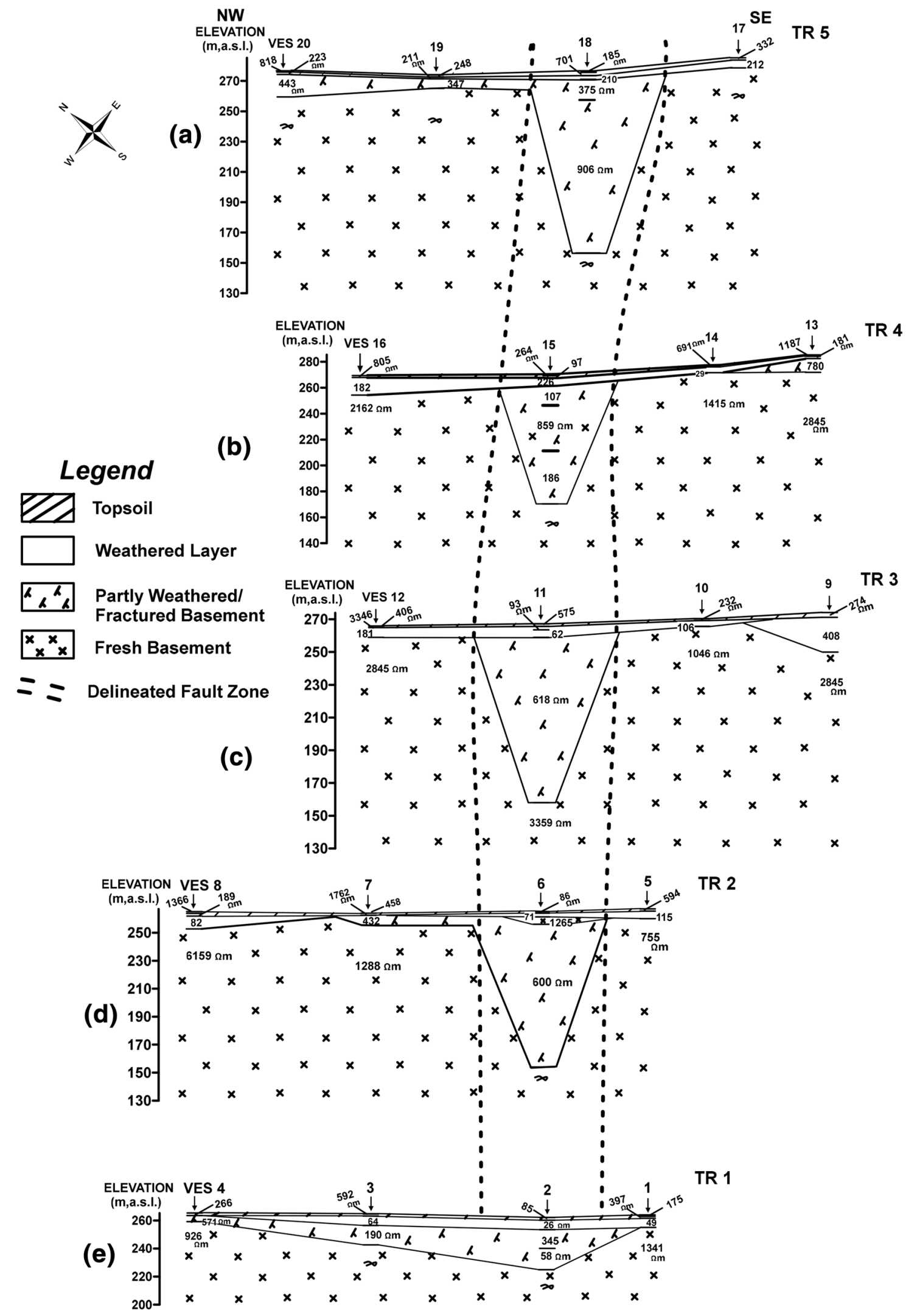

Fig. 10 Correlated geoelectric sections across traverses TR1-5 
Table 3 Electrical resistivity and lithological interpretation in the study area compared with other basement complex environment

\begin{tabular}{|c|c|c|c|c|c|}
\hline \multirow[t]{2}{*}{ Lithology } & \multicolumn{2}{|c|}{$\begin{array}{l}\text { Resistivity }(\Omega m) \text { (study area, } \\
\text { Nigeria) }\end{array}$} & \multirow{2}{*}{$\begin{array}{l}\text { Resistivity }(\Omega \mathrm{m}) \\
\text { (China) [23] } \\
\text { (From ERT) }\end{array}$} & \multirow{2}{*}{$\begin{array}{l}\text { Resistivity }(\Omega \mathrm{m}) \\
\text { (China) }[28] \\
\text { (From ERT) }\end{array}$} & \multirow{2}{*}{$\begin{array}{l}\text { Resistivity } \\
(\Omega \mathrm{m}) \text { (India) } \\
{[4]} \\
\text { (From VES) }\end{array}$} \\
\hline & (From ERT) & (From VES) & & & \\
\hline Topsoil & $87-1560$ & $68-1762$ & - & $18-345$ & 4-1000 \\
\hline Weathered layer & $99-398$ & $26-223$ & $22-345$ & $18-928$ & $30-120$ \\
\hline $\begin{array}{l}\text { Partly weathered/ } \\
\text { Fractured base- } \\
\text { ment }\end{array}$ & $20-700$ & $54-1625$ & $324-926$ & - & $120-500$ \\
\hline Fresh basement & $747-20,000$ & $755-\infty$ & $913-2579$ & $906-2595$ & $500-\infty$ \\
\hline
\end{tabular}

$E R T$ electrical resistivity tomography clayey weathered fault zone reduce the effective resistivity and give it low resistivity relative to the very resistive basement host rock. Variations in the resistivity values within the fault zone could indicate variable degree of weathering/fracturing and water saturation.

Except within the delineated fault zone, the weathering depth is shallow $(<14 \mathrm{~m})$ and the basement bedrock is fresh or poorly fissured judging from the very high resistivity values (generally $>1000 \Omega \mathrm{m}$ ). The partly weathered/ fractured basement columns with enhanced permeability were only identified within the fault zone. The VES points (e.g. VES 6, 11, 15 and 18) located within the axis of the identified structure gave high overburden thicknesses (partly weathered/fractured basement column). This structural feature could be adjudged to have high groundwater storage being over $5 \mathrm{~km}$ long with capacity for high groundwater yield due to enhanced permeability of the partly weathered and fractured basement column.

\subsection{Results Validation}

Drilling of exploratory boreholes is required for the validation of the aforementioned findings and for provision of direct information on the nature of the subsurface sequence, the structural disposition, the aquifer unit(s) and the hydrogeological characteristics. Although there is presently no exploratory borehole drilled within the present study area due to lack of fund, a borehole was recently drilled for domestic water supply at a site located about $3 \mathrm{~km}$ south-west of our study area and within a projected extension of the fault zone (Fig. 11a). The referenced borehole was located following a geophysical investigation involving 1D VES. The VES type curve is the HAKH ( $\rho_{1}$ $>\rho_{2}<\rho_{3}<\rho_{4}>\rho_{5}<\rho_{6}$ ) type (Fig. 11b) whose geoelectric/ geologic characteristics (Fig. 11c) are similar to what we observed at our survey area. The VES interpretation model identifies a fractured basement column as the main aquifer unit with a depth extent of $78 \mathrm{~m}$ and whose bottom is located at a depth of $130 \mathrm{~m}$. The borehole log delineated the subsurface sequence as predicted by the VES model with interfaces correlating within $\pm 0-15 \%$. The borehole was terminated at a depth of $85 \mathrm{~m}$ within less than half the depth extent of the fractured basement column (Fig. 11c) with a groundwater yield of $2.0 \mathrm{l} / \mathrm{s}$.

The groundwater potential rating of the study area is typical of a basement complex terrain which could range from very low to moderate and high (most especially within a fractured/faulted zone). This study shows that groundwater development is feasible within the fault zone via deep submersible pump operated borehole. It also demonstrates the effectiveness of integrated 1D and $2 \mathrm{D}$ electrical resistivity imaging and magnetic profiling in structure (fault) identification, characterization, subsurface sequence delineation and groundwater potential assessment in a typical basement complex environment.

\section{Conclusions}

Integrated electrical resistivity (1D and 2D) imaging and magnetic profiling techniques were used to characterize a strike slip fault in a basement complex terrain of Southwest Nigeria. The survey area is underlain by the grey gneiss and granite gneiss of the Precambrian Basement Complex.

The magnetic profiles, with amplitudes ranging from -97.5 to $+81.6 \mathrm{nT}$, are characterized by a major anomalous zone with two negative lows and a central high flanked by two generally low-amplitude positive shoulders characteristic of a thick dyke. The anomalous zones correlate across the traverses and trend approximately NE-SW. The northwestern edge of the magnetic anomalous zone coincides with the geo-referenced strike slip fault. The fault block (magnetic dyke) model has a width extent ranging from 112 to $152 \mathrm{~m}$, a depth extent in excess of $150 \mathrm{~m}$ and near vertical disposition in the south-east direction. The 2D resistivity structures delineate low resistivity near vertical discontinuities within the high resistivity fresh basement host rock that correlate across the five traverses investigated. The low resistivity anomalous zone correlates with 

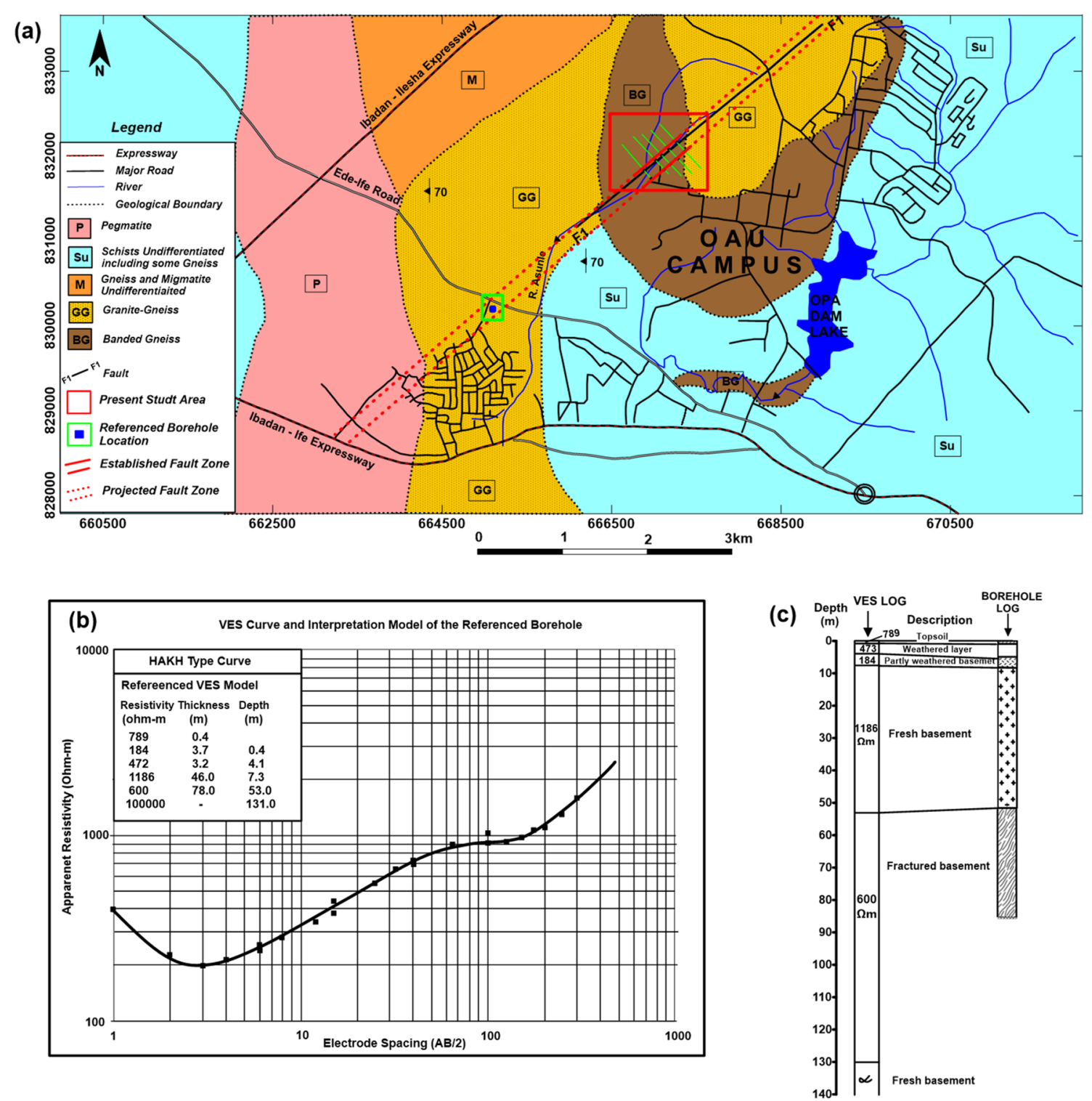

Fig. 11 a Geological map of part of lle-Ife (including the OAU) showing the established fault zone and its projection and the referenced borehole, $\mathbf{b}$ observed VES curve at a drilled site within the

the anomalous magnetic zone with the south-eastern edge of the latter slightly shifted to the right (slightly wider magnetic zone) [24]. The north-western edge of the resistivity anomalous zone also correlates with the georeferenced strike slip fault. The width of the low resistivity zone at the ground surface ranges from 75 to $125 \mathrm{~m}$ with depth extent in excess of $150 \mathrm{~m}$.

Four subsurface geologic/geoelectric layers were delineated. These include a relatively thin $(0.5-2.9 \mathrm{~m})$ clay/sandy clay/clayey sand/lateritic topsoil with layer resistivities of $68-1762 \Omega \mathrm{m}$ underlain by a clay/sandy clay weathered basement with layer thicknesses and resistivities of $0.9-14.1 \mathrm{~m}$ and $26-223 \Omega \mathrm{m}$, respectively; projected fault zone and c correlated VES interpretation model and borehole lithological log

a partly weathered/fractured basement column that is 4.7-117.4 m thick with layer resistivities of 54-1626 $\Omega \mathrm{m}$ and a basal fresh basement with resistivities of $755-\infty$ $\Omega \mathrm{m}$ and depth to rock head of 1.6-15.0 $\mathrm{m}$. The zone with thick column (up to $117 \mathrm{~m}$ ) of partly weathered/ fractured basement correlates across the five traverses and significantly with the anomalous magnetic and resistivity zones. The relatively thin (maximum of $14.1 \mathrm{~m}$ ) and clayey weathered layer and the partly weathered/fractured basement constitute the main aquifer units.

It can therefore be concluded that 
1. The OAU strike slip fault is characterized by relatively low resistivity and low (negative) total magnetic intensity typical of an iron ( $\mathrm{Fe}$ ) mineralized water-saturated fault zone [30];

2. The fault zone is significantly wide ( $>75 \mathrm{~m}$ ), steeply dipping and heavily fractured to deep depth (in excess of $150 \mathrm{~m}$ );

3. Except within the delineated fault zone, the overburden is thin and the basement rock is poorly fractured or fresh which explains the failure of the existing boreholes in the survey area; and

4. The significantly thick (up to $117 \mathrm{~m}$ ) partly weathered/ fractured basement column within the fault zone with enhanced permeability and storage capacities has potential for sustainable groundwater development.

\section{Compliance with ethical standards}

Conflict of interest The authors declare that they have no conflict of interest.

\section{References}

1. MMPGH (2019) Hydro-geophysical assessment for enhanced groundwater yield of a field of hand dug wells at the OAU MMPGH Complex, Ile-Ife, Osun State. Technical Report, Obafemi Awolowo University, lle-Ife: 26

2. Clark L (1985) Groundwater abstraction from basement complex areas of Africa. Quat J Eng Geol Lond 18:25-34

3. Olorunfemi MO, Fasuyi SA (1993) Aquifer types and the geoelectric/hydrogeologic characteristics of part of the Central basement terrain of Nigeria (Niger State). J Afr Earth Sci 16(3):309-317

4. Dewandel $B$, Lachassagne $P$, Wyns R, Marechal JC, Krishnamurthy NS (2006) A generalised 3-D geological and hydrogeological conceptual model of granite aquifers controlled by single or multiphase weathering. J Hydrol 330:260-284

5. Holdsworth RE, McCaffrey KJW, Dempsey E, Roberts NMW, Hardman K, Morton A, Feely M, Hunt J, Conway A, Robertson A (2019) Natural fracture propping and earthquake-induced oil migration in fracture basement reservoirs. Geology 47(8):700-704. https://doi.org/10.1130/G46280.1

6. Olorunfemi MO (2008) Voyage on the skin of the earth: a geophysical experience. Inaugural Lecture 211, Obafemi Awolowo University, Ile-Ife, Nigeria

7. Idornigie Al, Olorunfemi MO (1992) A geoelectric mapping of the basement structures of the south-central part of the bida basin and its hydrogeologic implications. J Min Geol 28(1):93-103

8. Olorunfemi MO, Ojo JS, Akintunde OM (1999) Hydro-geophysical evaluation of the groundwater potential of akure metropolis, Southwestern Nigeria. J Min Geol 35(2):207-228

9. Dan-Hassan MA, Olorunfemi MO (1999) Hydro-geophysical investigation of a basement terrain in the north-central part of Kaduna State Nigeria. J Min Geol 35(2):109-206

10. Ojo JS, Olorunfemi MO, Akintorinwa OJ, Bayode SO, Omosuyi GO, Akinluyi FO (2015) GIS integrated geomorphological, geological and geoelectrical assessment of the groundwater potential of akure metropolis, Southwest Nigeria. J Earth Sci Geotech Eng 5(14):85-101

11. Manu E, Agyekum WA, Duah AA, Tagoe R, Preko K (2019) Application of vertical electrical sounding for groundwater exploration of cape coast municipality in the central region of Ghana. Arab J Geosci 12:196. https://doi.org/10.1007/s12517-019-4374-4

12. Zohdy AAR, Eaton GP, Mabay DR (1974) Application of surface geophysics to groundwater investigation. In: Techniques of water resources investigation of the United States Geological Survey, Book 2, Chapter D1, 26-30

13. Satpathy BN, Kanungo DN (1976) Groundwater exploration in hard rock terrain: a case history. Geophys Prospect 24:725-756

14. Ojo AO, Olorunfemi MO (2013) Resistivity modelling of confined fractured basement column for varying thicknesses and depth of burial. Pac J Sci Technol 14(1):464-475

15. Ojo AO, Olorunfemi MO (2013) A graphical and semi-quantitative technique for investigating vertical electrical sounding (VES) curves for indices of confined fractured basement column. Pac J Sci Technol 14(2):537-550

16. Muchingami I, Hlatywayo DJ, Neil JM, Chuma C (2012) Electrical resistivity survey for groundwater investigation and shallow subsurface evaluation of the basaltic greenstone formation of the urban bulawayo aquifer. Phys Chem Earth 50-52:44-51

17. Kumar D (2012) Efficacy of electrical resistivity tomography technique in mapping shallow subsurface anomaly. J Geol Soc India 80:304-307

18. Ratnakumari Y, Rai SN, Thiagarajan S, Kumar D (2012) 2D electrical resistivity imaging for delineation of deeper aquifers in a part of the chandrabhaga river basin, Nagpar District Maharashtra, India. Curr Sci 102(1):62-69

19. Kumar D, Rao VA, Sarma VS (2014) Hydrogeological and geophysical study for deeper groundwater resource in quartzitic hard rock ridge region from $2 \mathrm{D}$ resistivity data. J Earth Syst Sci 123(3):531-543. https://doi.org/10.1007/s12040.014-0408-1

20. Mohamaden M (2016) Delineating groundwater aquifer and subsurface structures by using geoelectrical data: case study (Dakhla Oasis, Egypt). NRIAG J. Aston Geophys 5(1):247-253. https://doi.org/10.1016/j.nrjag.2016.05.001

21. Hasan M, Shang Y, Akhter G, Jin W (2017) Geophysical assessment of groundwater potential: a case study from mian Channu area, Pakistan. Groundwater 2017, https://doi.org/10.1111/ gwat.12617

22. Chirindja FJ, Dahlin T, Juizo D (2017) Improving the groundwater-well siting approach in consolidated rock in Nampula Province, Mozambique. Hydrogeol J 25:1423-1435

23. Gao Q, Shang Y, Hasan M, Jin W, Yang P (2018) Evaluation of a weathered rock aquifer using ERT method in South Guangdong China. Water 10:293. https://doi.org/10.3390/w10030293

24. Olorunfemi MO, Oni AG (2019) Integrated geophysical methods and techniques for sitting productive boreholes in basement complex terrain of Southwestern Nigeria. Ife J Sci 21(1):13-26. https://doi.org/10.4314/ijs.v21i1.1

25. Thapa BR, Shrestha SR, Neupane Okwany RO (2019) Shallow aquifer potential mapping in the foothills of churia in eastern gangetic plain of Saptari District Nepal. Appl Water Sci 9:92. https://doi.org/10.1007/s13201.019-0971-3

26. Sumanovac F, Dominkovic AS (2007) Determination of resolution limits of electrical tomography on the block model in a homogeneous environment by means of electrical modeling. Rudarsko-geolosko-naftni zbornik 19:47-56

27. Chandra S, Nagaiah E, Reddy DV, Ananda Rao V, Ahmed S (2012) Exploring deep potential aquifer in water scarce crystalline rocks. J Earth Syst Sci 121(6):1455-1468 
28. Hasan M, Shang Y, Jin W (2018) Delineation of weathered/fracture zones for aquifer potential using an integrated geophysical approach: a case study from South China. J Appl Geophys 157:47-60

29. Akinniranye OA (1985) Structure analysis of the basement complex of Obafemi Awolowo University Campus. B.Sc. Thesis, Obafemi Awolowo University, Ile-Ife

30. Olorunfemi MO, Olarewaju VO, Avci M (1986) Geophysical investigation of a fault zone-a case history from lle-Ife, Southwestern Nigeria. Geophys Prospect 34:1277-1284

31. Turner DC (1989) Upper proterozoic schist belts in the Nigerian sector of the pan-African Province of West Africa. In: Geology of Nigeria, Edited by C.A. Kogbe. Rock View (Nig.) Limited, Yakubu Gowon Way, Jos, Nigeria

32. Boesse JM (1989) A geological map of the Obafemi Awolowo University Campus, Ile-Ife. Thesis, Obafemi Awolowo University, Ile-Ife

33. Rahaman MA, Lancelot JR (1984) Continental crust evolution in SW Nigeria: constraints from U/Pb dating of Pan-African Gneiss. Earth Planets Sci Lett

34. Geomag (2019) magnetic field calculator-results, IGRF-12 (2015) Model. Retrieved October 30, 2019 (Modified February 8, 2019) from www.geomag

35. Wyns R, Baltassat $M$, Lachassagne $P$, Legchenko A, Varion J, Mathieu F (2004) Application of SNMR soundings for groundwater reservoir mapping in weathered basement rocks (Brittany, France). Bull Soc Geol Fr 175(1):21-34

36. McFarlane MJ (1989) A review of the development of tropical weathering profiles with particular references to leaching history and with examples from Malawi and Zimbabwe. In Groundwater Exploration and Development in Crystalline Basement Aquifers. Proceedings, Zimbabwe, June 1986. Vol II, Sessions 6-15. Commonwealth Science Council

37. Wright EP (1992) The hydrogeology of crystalline basement aquifers of africa. In: Wright EP, Burgess WG (eds) hydrogeology of crystalline basement aquifers of africa. Geological Society of London, London, pp 1-27

38. Acworth RI (1987) The development of crystalline basement aquifers in a tropical environment. Q J Eng Geol 20:265-272

39. Cho M, Ha KM, Choi YS, Kee WS, Lachassagne P, Wyns R (2003) Relationship between the permeability of hard-rock aquifers and their weathered cover based on geological and hydrogeological observation in South Korea. In: IAH conference on "Groundwater in Fractured Rocks", Prague, 15-19 September, 2003

40. Marechal J, Wyns R, Lachassagne P, Subrahmanyam K, Touchard F (2003) Vertical anisotropy of hydraulic conductivity in fissured layers of hard-rock: aquifer due to the geological structure of weathering profiles. Comptes Rendus Geosci 335(5):451-460. https://doi.org/10.1016/s1631-0713(03)00082-8

Publisher's Note Springer Nature remains neutral with regard to jurisdictional claims in published maps and institutional affiliations. 